\title{
Management of phytopathogens by application of green nanobiotechnology: Emerging trends and challenges
}

\author{
Mahendra Rai ${ }^{1,2}$ and Gabriela Kratosova ${ }^{2}$ \\ ${ }^{1}$ Nanobiotechnology Lab., Department of Biotechnology, SGB Amravati University, Amravati, India \\ ${ }^{2}$ Nanotechnology Centre, VSB - Technical University of Ostrava, Ostrava - Poruba, Czech Republic \\ mahendrarai@sgbau.ac.in and pmkrai@hotmail.com
}

\section{SUMMARY}

\begin{abstract}
Nanotechnology is highly interdisciplinary and important research area in modern science. The use of nanomaterials offer major advantages due to their unique size, shape and significantly improved physical, chemical, biological and antimicrobial properties. Physicochemical and antimicrobial properties of metal nanoparticles have received much attention of researchers. There are different methods i.e. chemical, physical and biological for synthesis of nanoparticles. Chemical and physical methods have some limitations, and therefore, biological methods are needed to develop environment-friendly synthesis of nanoparticles. Moreover, biological method for the production of nanoparticles is simpler than chemical method as biological agents secrete large amount of enzymes, which reduce metals and can be responsible for the synthesis and capping on nanoparticles.

Biological systems for nanoparticle synthesis include plants, fungi, bacteria, yeasts, and actinomycetes. Many plant species including Opuntia ficus-indica, Azardirachta indica, Lawsonia inermis, Triticum aestivum, Hydrilla verticillata, Citrus medica, Catharanthus roseus, Avena sativa, etc., bacteria, such as Bacillus subtilis, Sulfate-Reducing Bacteria, Pseudomonas stutzeri, Lactobacillus sp., Klebsiella aerogenes, Torulopsis sp., and fungi, like Fusarium spp. Aspergillus spp., Verticillium spp., Saccharomyces cerevisae MKY3, Phoma spp. etc. have been exploited for the synthesis of different nanoparticles. Among all biological systems, fungi have been found to be more efficient system for synthesis of metal nanoparticles as they are easy to grow, produce more biomass and secret many enzymes. We proposed the term myconanotechnology $($ myco $=$ fungi, nanotechnology $=$ the creation and exploitation of materials in the size range of 1-100 $\mathrm{nm}$ ). Myconanotechnology is the interface between mycology and nanotechnology, and is an exciting new applied interdisciplinary science that may have considerable potential, partly due to the wide range and diversity of fungi.

Nanotechnology is the promising tool to improve agricultural productivity though delivery of genes and drug molecules to target sites at cellular levels, genetic improvement, and nano-array based gene-technologies for gene expressions in plants and also use of nanoparticlesbased gene transfer for breeding of varieties resistant to different pathogens and pests. The nanoparticles like copper (Cu), silver (Ag), titanium (Ti) and chitosan have shown their potential as novel antimicrobials for the management of pathogenic microorganisms affecting agricultural crops. Different experiments confirmed that fungal hyphae and conidial germination of pathogenic fungi are significantly inhibited by copper nanoparticles. The nanotechnologies can be used for the disease detection and also for its management. The progress in development of nano-herbicides, nano-fungicides and nano-pesticides will open up new avenues in the field of management of plant pathogens. The use of different nanoparticles in agriculture will increase productivity of crop. It is the necessity of time to use nanotechnology in agriculture with extensive experimental trials. However, there are challenges particularly the toxicity, which is not a big issue as compared to fungicides and pesticides.
\end{abstract}

Keywords: Nanoparticles, pathogen detection, antimicrobials, nano-herbicides, nano-fungicides, nano-pesticides, toxicity

\section{INTRODUCTION}

Due to the extensive use of fungicides and pesticides there is rapid increase in ecotoxicity (Chen et al., 2015; $\mathrm{Vu}$ et al., 2015) and development of resistance in plant pathogenic microbes (Dzhavakhiya et al., 2012; Alghuthaymi et al., 2015). The possible solutions include biological control of plant pathogens by using extracts of the plants or microbes. Although, biological control methods for the management of phytopathogens have been useful, several inherent challenges need to be addressed (Frampton et al., 2012). Therefore, there is a pressing need to search for alternatives for the management of phytopathogens. The emerging nanobiotechnology seems to be of paramount importance for the management of phytopathogens particularly in early detection of plant disease, as potential fungicides, in development of varieties resistant to fungal diseases, and also for smart delivery of fungicides to the plants. The fungi affecting agricultural production can be controlled by application of nanofungicides. The use of nanotechnology both in developing and developed countries will bring dramatic changes in agriculture. This would really be a journey from green revolution to green nanobiorevolution.

Nanotechnology (NT) is highly interdisciplinary technology with size range of 1-100 nm. NT involves physics, chemistry, biology, engineering, medicines, agriculture and all other sciences. It is also considered as enabling technology since the property and activity of nanoparticles changes with change in size and shape (Satalkar et al., 2015).

Nanotechnology and biotechnology are two very important subjects, which are highly interdisciplinary. The fusion of these two subjects has given rise to Nanobiotechnology. The emerging science nanobiotechnology has revolutionized the world and it is believed that the present century will be the century of smart technologies represented by nanobiotechnology. There are various reports which provide evidence of in vitro efficacy of 
different kind of nanoparticles (Guo et al., 2015). But of course, the need of extensive experimental trials are necessary in order to utilize the fullest potential of nanobiotechnology. Different kind of nanoparticles in general and biodegradable nanoparticles in particular can be used for plant disease management (Chowdappa and Gowda, 2013).

Nanoparticles have higher surface area to the volume ratio. Therefore, they have more chances of interaction with the pathogenic microbes and killing them. As a matter of fact, they have better potential to kill the microbes as compared to bulk materials. The nanoparticles shows unique physical, chemical and biological properties due to their nanosize, and therefore can be utilized in gene transfer (Rai et al., 2012), for management of insect-pests in and pathogens in agriculture (Rai and Ingle, 2012; Mishra and Singh, 2015).

The bacteria and fungi are developing resistance to microbicides or fungicides and thus causing major problem for tackling the pathogens like Phytophthora. Considering this fact, it is a pressing need to develop alternative antimicrobial agents. Since ancient times, silver has been known for its antibacterial activity, and now silver nanoparticles are being used as antimicrobials (Rai et al., 2009). Encouragingly, AgNPs have been rightly called as nanoweapon against plant pathogens (Mishra and Singh, 2015). The American Biotech Labs have spent millions of dollars on testing the safety and efficacy of nanosilver technology products. Their studies have concluded that nanosilver products are not toxic to cells, animals or humans at low concentration.

Usually, the nanoparticles are synthesized by physical, chemical and biological methods. The first two methods are energy intensive and may require toxic chemicals whereas, biogenic technique is eco-friendly, clean, non-toxic and economically viable. However, the main draw-back of biogenic method is that it is difficult to achieve monodispersity, and control over the size and shape (Nayak et al., 2011). The formation of nanoparticles by using fungi (Ingle et al., 2009; Bawaskar et al., 2010; Kumar et al., 2012; Dar et al., 2013; Potara et al., 2015), plants (Narayan et al., 2008; Gade et al., 2010; Bonde et al., 2012; Rai and Yadav, 2013; Mallikarjunaet al., 2015) bacteria (Kumar et al., 2008; Shahverdi et al., 2009; Tiwari et al., 2014), actinomycetes (Golinska et al., 2014), algae (El-Kassas and El-Sheekh, 2014) have been reported by many researchers.

The main focus of the present talk is to discuss the role of green nanobiotechnology for the detection of diseases and also for the management of different phytopathogens in general and fungal pathogens in particular. In addition, the toxicity issue has also been addressed so that the nanofungicides may be formulated for the strategic management of plant diseases caused by different pathogens.

\section{NANOTECHNOLOGY IN PATHOGEN DETECTION}

There is increasing demand for the food production owing to the fast growing human population and therefore, food security has become an international issue. It is estimated that by 2050 an additional $70 \%$ food production is needed to fulfil the demand of growing population (Godfray et al., 2015). Unfortunately, the food loss caused by bacteria, fungi and viruses ranges from 20 to 40\% (Savary et al., 2012).

There are various recent methods for detection of diseases caused by microbial pathogens which are mostly laboratory-based (Fang and Ramasamy, 2015). These include polymerase chain reaction (PCR), enzyme-linked immunosorbent assay (ELISA), immunofluorescence (IF), fluorescence in-situ hybridization (FISH), flow cytometry (FCM) and gas chromatography-mass spectrometry (GC-MS). However, there is need of nanobiosensors for rapid detection of the pathogens (Rai et al., 2012). Many biosensors have been developed for different applications particularly in medical and environmental field. Such sensors can be developed for plant disease identification and their efficiency can be enhanced by the use of nanomaterials. Different nanomaterials, such as metal and metal oxide nanoparticles, quantum dots, carbon nanotubes, graphene, etc. can be used in nanobiosensors (Table 1). The nanoparticles are most widely used materials, for example, nanoparticles are used with antibodies for detection of Xanthomonas axonopodis (Yao et al., 2010).

Prunus necrotic ringspot virus (PNRSV), which causes disease in Prunus species (peach, plum, apricot, sweet cherry and almonds) resulting into yield loss. Traditionally, the trees which suffer from disease have to remove from the orchard. Hence, the rapid and early identification of the pathogen is necessary in order to control this disease. In 2014, Zong et al. developed a new method for rapid detection of Prunus necrotic ringspot virus using magnetic-nanoparticle-based reverse Transcription loop-mediated isothermal amplification (RTLAMP). The authors reported this technique to be highly specific and more sensitive to PNRSV than than reverse-transcription polymerase chain reaction (RT-PCR). 
List of different nanomaterials used in nanobiosensors

\begin{tabular}{|l|l|l|l|}
\hline S.No. & Nanomaterials & Disease & Reference \\
\hline 1 & AuNps-based optical immunosensor & $\begin{array}{l}\text { Karnal bunt disease of } \\
\text { wheat }\end{array}$ & Singh et al. (2010) \\
\hline & $\begin{array}{l}\text { Gold nanorods (AuNRs) functionalized by } \\
\text { antibodies }\end{array}$ & $\begin{array}{l}\text { Cymbidium mosaic virus } \\
\text { (CymMV) or } \\
\text { Odontoglossum ringspot } \\
\text { virus (ORSV) }\end{array}$ & Singh et al. (2010) \\
\hline 2 & Nanochips (made of microarray) & Bacteria and viruses & López et al. (2009) \\
\hline 3 & Fluorescent silica nanoparticles (FSNPs) & $\begin{array}{l}\text { Xanthomonas axonopodis } \\
\text { pv. vesicatoria }\end{array}$ & Yao et al. (2009) \\
\hline 4 & Quantum dots-based sensors & $\begin{array}{l}\text { General disease detection, } \\
\text { viruses }\end{array}$ & $\begin{array}{l}\text { Algar and Krull (2008); } \\
\text { Safarpour } \text { et al. (2012) }\end{array}$ \\
\hline 5 & SnO and TiO 2 & $\begin{array}{l}\text { General disease, detection } \\
\text { of p-ethylguaiacol secreted } \\
\text { by infected strawberry }\end{array}$ & Fang et al. (2014) \\
\hline 6 & $\begin{array}{l}\text { Polymers such as polypyrrole (PPy) } \\
\text { nanoribbon modified chemiresistive sensors }\end{array}$ & $\begin{array}{l}\text { Cucumber mosaic virus } \\
\text { (CMV) }\end{array}$ & James (2013) \\
\hline 7 & $\begin{array}{l}\text { Magnetic-nanoparticl-based reverse } \\
\text { transcription loop-mediated isothermal } \\
\text { amplification (RT-LAMP) }\end{array}$ & $\begin{array}{l}\text { Prunus necrotic ring-spot } \\
\text { virus (PNRSV) }\end{array}$ & Zong et al. (2014) \\
\hline
\end{tabular}

\section{NANOANTIMICROBIALS FOR TACKLING THE PROBLEM OF PLANT PATHOGENS}

The use of metals as antimicrobials against pathogens is well known since ancient times. The metals such as copper, silver, palladium, ruthenium and their compounds have been used against human and plant diseases (Medici et al., 2015). With the advent of nanobiotehnology, different nanomaterials including nanoparticles have been evaluated for their potential for the management of plant pathogens (Table 2). Cioffi and his collaborators in 2004 studied antifungal activity of nanocopper against plant pathogenic fungi. Gul et al. (2014) presented an informative review on role of nanotechnology in crop protection.

Lamsal and his colleagues in 2011 evaluated different concentrations of AgNPs against powdery mildew and found that $100 \mathrm{ppm}$ silver nanoparticles $(7-25 \mathrm{~nm})$ demonstrated highest inhibition rate of the disease in cucumbers and pumpkins in field conditions. In 2011, they further studied different concentrations (10, 30, 50, and $100 \mathrm{ppm}$ ) of AgNPs on six species of Colletotrichum including C. acutatum, C.dematium, C. gloeosporioides, C. higginsianum, C. nigrum and C. orbiculare and reported the significant inhibition of growth of all the species of Colletotrichum tested in their experiment. They also reported that the treatment should be given to the plants before appearance of the symptoms on the host plants. Encouragingly, the highest percentage of inhibition was recorded with 50 ppm nanoparticles in field trials while 100 ppm AgNPs was needed in vitro inhibition.

Ocsoy and his colleagues (2013) on their study found leaf-spot disease caused by Xanthomonas perforans (Cu resistant) can be inhibited by DNA-directed silver (Ag) nanoparticles (NPs). The in vitro studies and nanoparticle-treated plants demonstrated that at $16 \mathrm{ppm}$ the growth was inhibited, which provides evidence of remarkable antibacterial activity against $X$. perforans. The disease was significantly reduced, when $100 \mathrm{ppm}$ Ag@dsDNA@GO was applied in green house experiment.

In another study, the biogenically synthesized nanoparticles by leaves and stem of Piper nigrum were tested against two bacteria, namely, Citrobacter freundii and Erwinia cacticida causing diseases on Abelmoschus esculentus and citrullus lanatus. The authors reported excellent antibacterial activity when silver nanoparticles impregnated antibiotic discs (Chloramphenicol) were used against the test bacteria (Paulkumar et al. 2014). Interestingly, Anusuya and Sathiyabama (2014) applied chitosan nanoparticles to induce antifungal hydrolases in turmeric plant (Curcuma longa). The author performed foliar spray of chitosan nanoparticles and found that chitinases and chitosanases were increased. 
List of different nanomaterials and nanocomposites used against phytopathogens

\begin{tabular}{|c|c|c|c|}
\hline S.No. & Type of Nanoparticles & Phytopathogens & References \\
\hline 1 & Copper nanoparticles & Antifungal & Cioffi et al. (2004) \\
\hline 2 & Silica-silver nanoparticles & $\begin{array}{l}\text { Rhizoctonia solani, Pythium ultimum, Botrytis cinerea, } \\
\text { Magnaporthe grisea and Colletotrichum } \\
\text { gloeosporioides }\end{array}$ & Park et al. (2006) \\
\hline 3 & AgNPs & $\begin{array}{l}\text { Bipolaris sorokiniana and } \\
\text { Magnaporthe grisea }\end{array}$ & Jo et al. (2009) \\
\hline 4 & AgNPs & Sclerotium-forming phytopathogenic fungi & Min et al. (2009) \\
\hline 5 & AgNPs & Oak wilt pathogen Raffaelea sp. & Kim et al. (2009) \\
\hline 6 & AgNPs & $\begin{array}{l}\text { Stem-end bacteria on cut gerbera Gerbera jamesonii) } \\
\text { cv. Ruikou }\end{array}$ & Liu et al. (2009) \\
\hline 7 & AgNPs & Fusarium culmorum & Kasprowicz et al. (2010) \\
\hline 8 & AgNPs & Powdery mildew on cucumber and pumpkin & Lamsal et al. (2011) \\
\hline 9 & AgNPs & $\begin{array}{l}\text { Colletotrichum acutatum, C. dematium, C. } \\
\text { gloeosporioides, C. higginsianum, C. nigrum, C. } \\
\text { orbiculare }\end{array}$ & Lamsal et al. (2011) \\
\hline 10 & AgNPs & Cut Acacia holosericea & Liu et al. (2012) \\
\hline 11 & AgNPs colloidal solution & $\begin{array}{l}\text { Alternaria alternata, A. brassicicola, A. solani, Botrytis } \\
\text { cinerea, Cladosporium cucumerinum, Corynespora } \\
\text { cassiicola, Cylindrocarpon destructans, Didymella } \\
\text { bryoniae, Fusarium oxysporum f.sp. cucumerinum, } \\
\text { Fusarium oxysporum f.sp. lycopersici, Fusarium } \\
\text { oxysporum, Fusarium solani, Glomerella cingulata, } \\
\text { Monosporascus cannoballus, Pythium } \\
\text { aphanidermatum, } P \text {. spinosum, Stemphylium lycopersici }\end{array}$ & Kim et al. (2012) \\
\hline 12 & Nanosized Ag-silica-hybrid & Pseudomonas syringae pv. tomato & Chu et al. (2012) \\
\hline 13 & $\begin{array}{l}\text { DNA-directed silver (Ag) } \\
\text { nanoparticles (NPs) }\end{array}$ & $\begin{array}{l}\text { Bacterial spots caused by Xanthomonas perforans in } \\
\text { tomatoes }\end{array}$ & Ocsoy et al. (2013) \\
\hline 14 & Chitosan NPs & $\begin{array}{l}\text { Rhizome-Rot Disease of Turmeric Caused by Pythium } \\
\text { aphanidermatum }\end{array}$ & Anusuya and Sathiyabama (2013) \\
\hline 15 & Silver - chitosan composite & Gray mold (Botrytis cinerea) in straberry & Moussa et al. (2013) \\
\hline 16 & $\begin{array}{l}\text { ß- D - glucan } \\
\text { nanoparticles }\end{array}$ & $\begin{array}{l}\text { Rhizome-Rot Disease of Turmeric Caused by Pythium } \\
\text { aphanidermatum }\end{array}$ & Anusuya and Sathiyabama (2014) \\
\hline 17 & Biogenic AgNPs & $\begin{array}{l}\text { Bipolaris sorokiniana causing Spot Blotch Disease in } \\
\text { Wheat }\end{array}$ & Mishra et al. (2014) \\
\hline 18 & AgNPs & Citrobacter freundii, Erwinia cacticida & Paulkumar et al. (2014) \\
\hline 19 & Silica NPs & Fusarium oxysporum and Aspergillus niger & Suriyaprabha et al. (2014) \\
\hline 20 & Copper NPs & $\begin{array}{l}\text { Fusarium oxysporum, Curvularia lunata, Alternaria } \\
\text { alternata, and Phoma destructiva }\end{array}$ & Kanhed et al. (2014) \\
\hline 21 & Nanotitania & Alternaria brassicae & Palmqvist et al. (2015) \\
\hline 22 & AgNPs & $\begin{array}{l}\text { Phytophthora parasitica, } P \text {. infestans, } P \text {. palmivora, } P \text {. } \\
\text { cinnamomi, } P \text {. tropicalis, } P \text {. capsici, and } P \text {. katsurae }\end{array}$ & Ali et al. (2015) \\
\hline 23 & Cu-Chitosan NPs & $\begin{array}{l}\text { Alternaria solani and Fusarium oxysporum pathogenic } \\
\text { fungi of tomato }\end{array}$ & Saharan et al. (2015) \\
\hline 24 & Chitosan NPs & F. oxysporum f.sp. lycopersici in tomato & Sathiyabama and Charles (2015) \\
\hline
\end{tabular}

These enzymes are responsible for defense of the host plants. The treated plants of $C$. longa were found to be resistant to Pythium aphanidermatum, the causal organism of rhizome-rot of turmeric. In 2014, they also applied ß-D-glucan nanoparticles, which reduced rot incidence by 23.3\%. The authors found correlation between reduction on incidence of rhizome-rot and enhanced activity of defense enzymes such as peroxidases, polyphenol oxidases, protease inhibitors and ß-1,3-glucanases.

Mishra et al. (2014) synthesized AgNPs by using Serratia sp. and evaluated these AgNPs against spot blotch disease in wheat caused by Bipolaris sorokiniana. The AgNPs demonstrated remarkable antifungal activity when 2, 4 and $10 \mathrm{mg} / \mathrm{ml}$ concentrations were used. The conidial germination of B. sorokiniana was totally inhibited. In an interesting experiment, Suriyaprabha and colleagues (2014) treated maize with silica NPs (20-40 nm) to know the resistance against two important phytopathogens, Fusarium oxysporum and Aspergillus niger. The authors reported development of higher resistance in Silica nanoparticle treated maize plants than the bulk silica treated plants. In an interesting study, Palmqvist and colleagues (2015) used Titania NPs to understand the interaction between Bacillus amyloliquefaciens, a plant growth promoting bacterium and the host plant Brassica napus for providing protection against Alternaria brassicae. The authors observed increased number of bacteria on the roots of $B$. napus due to use of Titania NPs., which protects the test plant against infection caused by $A$. brassicae. 


\section{NANOTOXICITY: A MAJOR CHALLENGE}

As discussed in the earlier sections nanoparticles have huge applicability for the management of plant diseases. But due to increased applications there is greater possibilities of getting accumulated in the environment and cause the harmful effects. By any kind of aqueous medium there are high chances of accumulation of nanoparticles in soil resulting into the soil ecosystem toxicity. Thus, if accumulated above certain limit they will bound to show the harmful effects. For instance, a study has shown that $\mathrm{TiO}_{2}$ and $\mathrm{ZnO}$ nanoparticles have negatively affected the biomass of wheat growth and also inhibited the activities of soil enzymes such as protease, catalase and peroxidase activities, thereby affecting the soil quality and health (Du et al., 2011). Yang and Watts (2005) were the first to report about the nanotoxicity to plants through the soil. According to their study $\mathrm{Al}_{2} \mathrm{O}_{3}$ conjugated with and without phenanthrene affected the root elongation of Zea mays, Cucumis sativus, Glycine max, Brassica oleracea and Daucus carota. Similar results were obtained by exposing $\mathrm{MWNT}, \mathrm{Al}_{2} \mathrm{O}_{3}, \mathrm{Al}, \mathrm{Zn}$ and $\mathrm{ZnO}$ on radish, rape, ryegrass, lettuce, corn, and cucumber. With affecting the root elongation, those nanoparticles also shown to affect the plant germination (Lin and Xing, 2007). $\mathrm{TiO}_{2}$ were reported to reduce the water usage in Z. mays and changes the path of apoplast (Asli and Neumann, 2009). Palladium nanoparticles (PdNPs) were reported to get accumulated in leaves of barley (Battke et al., 2008). Therefore, there is possibility of transfer of these nanoparticles in the animals. On the similar way, nano $\mathrm{Fe}_{2} \mathrm{O}_{3}$ were also found to get accumulated in tissue of pumkin (Zhu et al., 2008).Through an interesting study Lin et al. (2009) reported the transmission of $\mathrm{C}_{70}$ into the progeny of nanoparticle exposed rice.

All of the reports suggest that as a consequence of presence of various nanoparticles in soil, there is possibility of threat to soil microorganisms and to plants by absorption of nanoparticles from soil. Moreover, such accumulation and/or toxic effects to plants may affect the complete food chain. The toxic effects to plants may further pass to animals such as fish, insects or mammals including humans who consume them (Figure 1). But still there is huge knowledge gap in the information on the mode of uptake of nanoparticles and consequences of their exposure to soil environment. There is also need to study the impact of surface functionalization, size, charge, agglomeration and stability of nanoparticles on the plants. Moreover, it is also essential to perform further studies on the transport of nanoparticles and the effects caused to food chain thereby affecting the humans and animals.

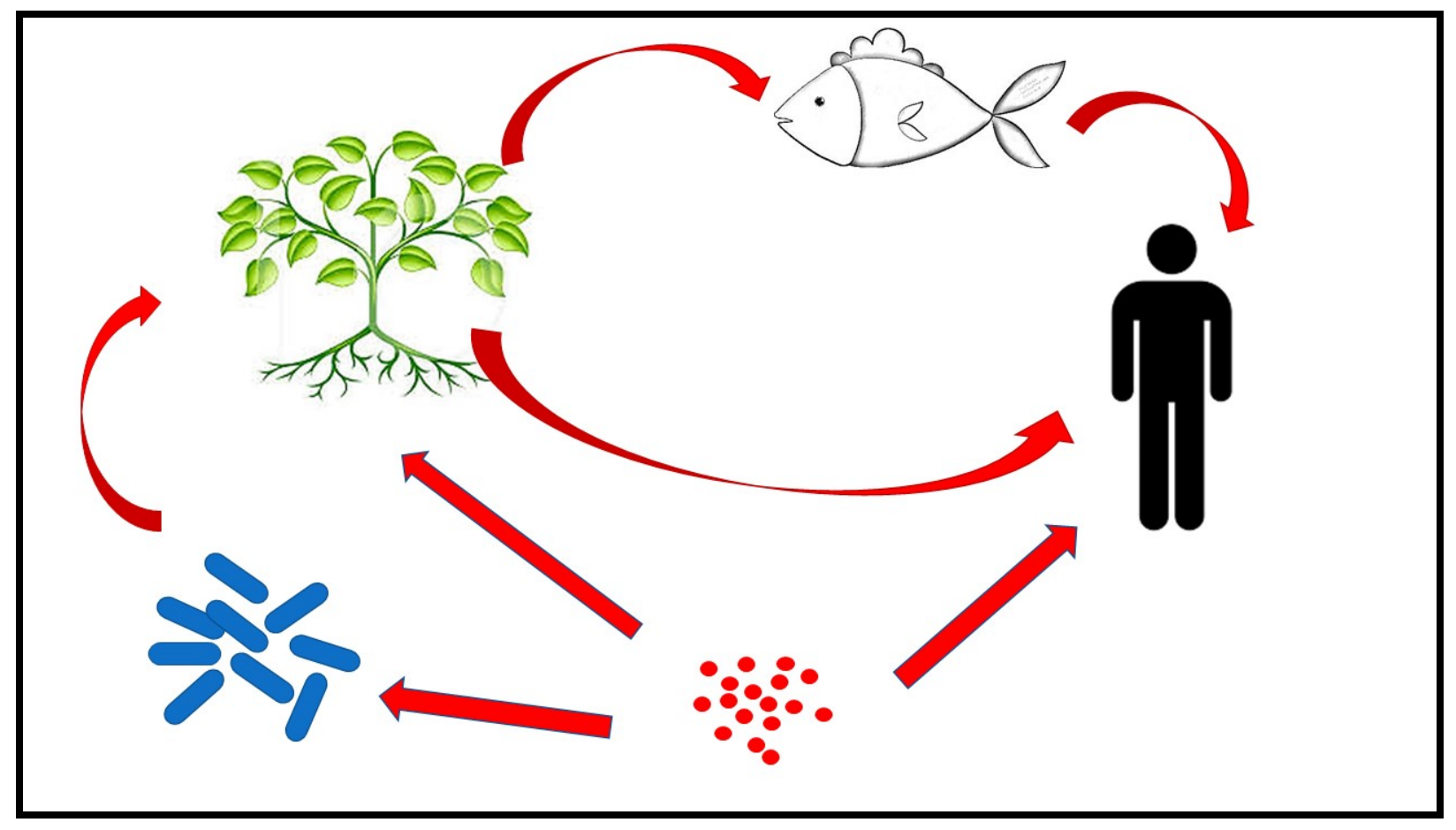

Figure 1: Fate of nanoparticles in the soil environment. The nanoparticles may exert toxic effects to soil bacteria and plants, and if accumulated inside them, they can be ultimately transferred to animals and humans

The straight red colored lines show the direct effect of nanoparticles. The curved red lines show the pathway of nanoparticles in food chain. 


\section{CONCLUSIONS}

It can be concluded that extensive application of chemical fungicides and antimicrobials have generated huge pollution resulting into toxicity to all the living flora and fauna. Considering this fact, it is felt that there is an urgent need to search for alternatives to manage the phytopathogens for the sustainable plant production. The application of biocontrol agents for the management of different diseases is an interesting strategy but there are several inherent issues, which prompts us to search for other viable alternatives, and therefore, the use of eco-friendly green nanobiotechnology has become the main focus of the scientists all over the world. The synthesis of nanomaterials by biogenic methods mainly microbes and plants is green, eco-friendly, rapid and economically viable. These can be utilized for the development of nanobiosensors, which can be used for the detection of plant diseases. Moreover, different types of nanomaterials in general and nanoparticles in particular may solve the problem of microbes resistant to microbicides or fungicides. In addition, the pollution and toxicity of fungicides can be avoided. However, extensive experimental field trials are needed to understand the toxicity of the nanoparticles in food chain. Finally, the application of green nanobiotechnology may open up new avenues for research pertaining to the management of plant pathogens.

\section{ACKNOWLEDGEMENT}

This paper was elaborated with the financial support of the project MSMT CR IRP 207/2015.

\section{REFERENCES}

Algar W.R. - Krull U.J. (2008): Quantum dots as donors in fluorescence resonance energy transfer for the bioanalysis of nucleic acids, proteins, and other biological molecules. Analytical and Bioanalytical Chemistry 391: 1609-1618.

Alghuthaymi M.A. - Almoammar H. - Rai M. - Said-Galiev E. - Abd-Elsalam K.A. (2015): Myconanoparticles: synthesis and their role in phytopathogensmanagement.Biotechnology and Biotechnological Equipment 29(2): 221-236.

Anusuya S.-Sathiyabama M. (2013): Effect of chitosan on rhizome rot disease of turmeric caused by Pythiumaphanidermatum. ISRN Biotechnology 2014:305349. doi: 10.1155/2014/305349.

Asli S. - Neumann P. M. (2009): Colloidal suspensions of clay or titanium dioxide nanoparticles can inhibit leaf growth and transpiration via physical effects on root water transport. Plant Cell and Environment 32: 577-584.

Battke F. - Leopold K. - Maier M. - Schmidhalter U. - Schuster M. (2008): Palladium exposure of barley: uptake and effects. Plant Biology10: 272-276.

Bawaskar M. - Gaikwad S. - Ingle A. - Rathod D. - Gade, A. - Duran N. - Marcato P.D. - Rai M. (2010): A New Report on Mycosynthesis of Silver Nanoparticles by Fusarium culmorum. Current Nanoscience 6: 376-380.

Bonde S.R. - Rathod D.P. - Ingle A.P. - Ade R.B. - Gade A.K. - Rai M.K. (2012): Murrayakoenigii mediated synthesis of silver nanoparticles and its activity against three human pathogenic bacteria. Nanoscience Method s 1: 25-36.

Chen L. - Song Y. - Tang B. - Song X. - Yang H. - Li B. - Zhao Y. - Huang C .- Han X. - Wang S. -Li Z. (2015): Aquatic risk assessment of a novel strobilurin_fungicide: A microcosm study compared with the species sensitivity distribution approach. Ecotoxicology and Environmental Safety doi: 10.1016/j.ecoenv.2015.06.027.

Chowdappa P. - Gowda S. (2013): Nanotechnology in crop protection: Status and scope. Pest Management in Horticultural Ecosystems 19 (2):131-151.

Cioffi N. - Ditaranto T. L. - Sabbatini N. - Zambonin L. - Tantillo P.G. - Ghibelli G. - D’Alessio L. - Bleve-Zacheo M. - Traversa E. (2004): Antifungal activity of polymer-based copper nano-composite coatings. Applied Physics Letters 85: 2417-2419.

Dar M.A. - Ingle A. - Rai M. (2013): Enhanced antimicrobial activity of silver nanoparticles synthesized by Cryphonectria sp. Evaluated singly and in combination with antibiotics. Nanomedicine: Nanotechnology, Biology and Medicine 9: 105-110.

Du W. - Sun Y. - Ji R. - Zhu J. - Wub J. - Guo H. (2011): TiO2 and ZnO nanoparticles negatively affect wheat growth and soil enzyme activities in agricultural soil. Journal of Environmental Monitoring 13: 822-828.

Dzhavakhiya V. - Shcherbakova L. - Semina Y. - Zhemchuzhina N. - Campbell B. (2012): Chemosensitization of plant pathogenic fungi to agricultural fungicides. Front Microbiology 3: 1-9.

El-Kassas H.Y. - El-Sheekh M.M. (2014): Cytotoxic activity of biosynthesized gold nanoparticles with an extract of the red seaweed Corallina officinalis on the MCF-7 human breast cancer cell line. Asian Pacific journal of cancer prevention 15(10): 4311-4317.

Fang Y. - Ramasamy R. P. (2015): Current and Prospective Methods for Plant Disease Detection. Biosensors 4: 537-561.

Fang Y. - Umasankar Y. - Ramasamy R. P. (2014): Electrochemical detection of p-ethylguaiacol, a fungi infected fruit volatile using metal oxide nanoparticles. Analyst 139: 3804-3810.

Frampton R.A. - Pitman A.R. - Fineran P.C. (2012): Advances in bacteriophage-mediated control of plant pathogens. International Journal of Microbiology doi: 10.1155/2012/326452.

Gade A. - Gaikwad S. - Tiwari V. - Yadav A. - Ingle A. - Rai M. (2010): Biofabrication of Silver Nanoparticles by Opuntiaficus indica: In vitro antibacterial activity and study of the mechanism involved in the synthesis. Current Nanoscience 6: 370-375.

Godfray H.C.J. - Beddington J. R. - Crute I. R. - Haddad L. - Lawrence D. - Muir J. F. - Pretty J. - Robinson S. - Thomas S. M. - Toulmin C. (2010): Food security: The challenge of feeding 9 billion people. Science 327: 812-818. 
Golinska' P. - Wypij M. - Ingle A.P. - Gupta I. - Dahm H. - Rai M. (2014): Biogenic synthesis of metal nanoparticles from Actinomycetes: Biomedical applications and cytotoxicity. Applied Microbiology and Biotechnology 98: 8083-8097.

Gul H.T. - Saeed S. - Khan F.Z.A. - Manzoor S.A. (2014): Potential of Nanotechnology in Agriculture and Crop Protection: A review. Applied Science and Business Economics 2:23-28.

Guo B.L. - Han P. - Guo L.C. - Cao Y.Q. - Li A.D. - Kong J.Z. - Zhai H.F. - Wu D. (2015): The Antibacterial activity of Ta-doped ZnO nanoparticles. Nanoscale Research Letters 10(1): 1047. DOI:10.1186/s11671-015-1047-4

Ingle A. - Gade A. - Bawaskar M. - Rai M. (2009): Fusarium solani: a novel biological agent for the extracellular synthesis of silver nanoparticles. Journal of Nanoparticle Research 11: 2079-2085.

James C. (2013): Polypyrrolenanoribbon based chemiresistiveimmunosensors for viral plant pathogen detection. Analytical Methods 5: 3497-3502.

Kanhed P. - Birla S. - Gaikwad S. - Gade A. - Seabra A. - Rubilar O. - Duran N. - Rai M. (2014): In vitro antifungal efficacy of copper nanoparticles against selected crop pathogenic fungi, Material letters, 115: 13-17.

Kumar R. - Priyadharsani K. - Thamaraiselvi K. (2012): Mycogenic synthesis of silver nanoparticles by the Japanese environmental isolate Aspergillus tamarii. Journal of Nanoparticle Research 14: 860.

Kumar U. - Shete A. - Harle A.S. - Kasyutich O. - Schwarzacher W. - Pundle A. - Poddar P. (2008): Extracellular bacterial synthesis of protein-functionalized ferromagnetic $\mathrm{Co}_{3} \mathrm{O}_{4}$ nanocrystals and imaging of self-organization of bacterial cells under stress after exposure to metal ions. Chemistry of Materials 20: 1484-1491.

Lamsal K. - Kim S.W. - Jung J.H. - Kim Y.S. - Kim K.S. - Lee Y.S. (2011): Application of silver nanoparticles for the control of Colletotrichum species in vitro and pepper anthracnose disease in field. Mycobiology 39(3): 194-199.

Lamsal K. - Kim S.W. - Jung J.H. - Kim Y.S. - Kim K.S. - Lee Y.S. (2011): Inhibition effects of silver nanoparticles against powdery Mildews on Cucumber and Pumpkin. Mycobiology 39(1): 26-32.

Lin D. - Xing B. (2007): Phytotoxicity of nanoparticles: inhibition of seed germination and root growth. Environmental Pollution 150: 243250.

Lin S. - Reppert J. - Hu Q. - Hudson J.S. - Reid M.L. - Ratnikova T. A. - Rao A. M. - Luo H. - Ke P.C. (2009): Uptake translocation and transmission of carbon nanomaterials in rice plants. Nano micro Small 5:1128-1132.

Liu J. - Ratnayake K. - Joyce D.C. - He S. - Zhang Z. (2012): Effects of three different nano-silver formulations on cut Acacia holosericea vase life. Postharvest Biology and Technology 66: 8-15.

López M. M. - Lop P. - Olmos A. - Marco-Noales E. - Cambra M. - Bertolini E. (2009): Are molecular tools solving the challenges posed by detection of plant pathogenic bacteria and viruses?. Current Issues in Molecular Biology 11:13-46.

Mallikarjuna K. - Narasimha G. - John Sushma N. - Dillip G.R. - Subba Reddy B.V. - Sreedhar B. - Deva Prasad Raju B. (2015): Biogenic preparation of Gold nanostructures reduced from Piper longum leaf broth and their electrochemical studies. Journal of Nanoscience and Nanotechnology 15(2): 1280-1286.

Medici, S.- Massimiliano Peana- Valeria Marina Nurchi- Joanna I. Lachowicz- Guido Crisponi- Maria Antonietta Zoroddu (2015): Noble metals in medicine: Latest advances, Coordination Chemistry Reviews, 284: 329-350

Mishra S.-Singh B. R.-Singh A.-Keswani C.-Naqvi A. H.-Singh H. B. (2014): Biofabricated silver nanoparticles act as a strong fungicide against Bipolarissorokiniana causing spot blotch disease in wheat. PLoS One 9(5): e97881.

Mishra S.-Singh H.B. (2015): Biosynthesized silver nanoparticles as a nanoweapon against phytopathogens: exploring their scope and potential in agriculture. Applied Microbiology and Biotechnology 99:1097-1107.

Narayanan K.B.-Sakthivel N. (2008): Coriander leaf mediated biosynthesis of gold nanoparticles. Materials Letters 62:4588-4590.

Nayak R.-Pradhan N.-Behera D.-Pradhan K.-Mishra S.-Sukla L.-Mishra B. (2011): Green synthesis of silver nanoparticle by Penicilliumpurpurogenum NPMF: the process and optimization. Journal of Nanoparticle Research 13: 3129-3137.

Ocsoy I.- Mathews L.-Paret.-Ocsoy M.A.-Kunwar S.- Chen T.-You M.-Tan W. (2013): Nanotechnology in plant disease management: DNAdirected silver nanoparticles on Graphene oxide as an antibacterial against Xanthomonasperforans. ACS Nano7 (10):8972-8980.

Ocsoy I. - Paret M.L. - Ocsoy M. A. - Kunwar S. - Chen T. - You M. - Tan W. (2013): Nanotechnology in plant disease management: DNAdirected silver nanoparticles on graphene oxide as an antibacterial against Xanthomonas perforans. ACS Nano 7(10): $10.1021 / \mathrm{nn} 4034794$.

Palmqvist N.G.M. - Bejai S. - Meijer J. - Seisenbaeva G.A. - Kessler V.G. (2015): Nano titania aided clustering and adhesion of beneficial bacteria to plant roots to enhance crop growth and stress management. Scientific Report 5: 10146.

Paulkumar K. - Gnanajobitha G. - Vanaja M. - Rajeshkumar S. - Malarkodi C. - Pandian K. - AnnaduraiG. (2014): Piper nigrum leaf and stem assisted green synthesis of silver nanoparticles and evaluation of its antibacterial activity against agricultural plant pathogens. The Scientific World Journal. http://dx.doi.org/10.1155/2014/829894.

Potara M. - Bawaskar M. - Simon T. - Gaikwad S. - Licarete E. - Ingle A. - Banciu M. - Vulpoi A. - Astilean S. - Rai M. (2015): Biosynthesized silver nanoparticles performing as biogenic SERS-nanotags for investigation of C26 colon carcinoma cells. Colloids and Surfaces B: Biointerfaces, 133: 296-303.

Rai M. K. - Gade A.K. - Gaikwad S. - Marcato P. D. - Duran N. (2012): Biomedical applications of nanobiosensors: The state-of-the-art. Journal of Brazilian Chemical Society 23(1): 14-24.

Rai M. K. - Yadav A.P. - Gade A.K. (2009): Silver nanoparticles as a new generation of antimicrobials. Biotechnology Advances 27(1): 7682.

Rai M. - Ingle A. (2012): Role of nanotechnology in agriculture with special reference to management of insect pests. Applied Microbiology and Biotechnology 94:287-93.

Rai M.K. - Deshmukh S.D. - Gade A.K. - Kamel A.E. (2012): Strategic nanoparticle- mediated gene transfer in plants and animals- a novel approach. Current Nanoscience 8:170-179. 
Safarpour H. - Safarnejad M. R. - Tabatabaei M.-Mohsenifar A. - Rad F. - Basirat M. - Shahryari F. - Hasanzadeh F. (2012): Development of a quantum dots FRET-based biosensor for efficient detection of Polymyxa betae. Canadian Journal of Plant Pathology 34: 507-515.

Satalkar P. - Elger B.S. - Shaw D.M. (2015): Defining Nano, Nanotechnology and Nanomedicine: Why Should It Matter? Science and Engineering Ethics[Epub ahead of print].

Sathiyanarayanan A. - Muthukrishnan S. (2013): Effect of chitosan on rhizome rot disease of turmeric caused by Pythium aphanidermatum. ISRN Biotechnology http://dx.doi.org/10.1155/2014/305349.

Savary S. - Ficke A. - Aubertot J. - Hollier C. (2012): Crop losses due to diseases and their implications for global food production losses and food security. Food Security 4: 519-537.

Shahverdi A.R. - Minaeian S. - Shahverdi H.R. - Jamalifar H. - Shahverdi N. - Wong C.W. - NurYasumira A.A. (2009): Rapid biosynthesis of silver nanoparticles using culture supernatant of bacteria with microwave irradiation. E-Journal of Chemistry 6(1): 61-70.

Singh S. - Singh M. - Agrawal V.V. - Kumar A. (2010): An attempt to develop surface plasmon resonance based immunosensor for Karnal bunt (Tilletia indica) diagnosis based on the experience of nano-gold based lateral flow immuno-dipstick test. Thin Solid Films 519: 1156-1159.

Tiwari M. - Narayanan K. - Thakar M.B. - Jagani H.V. - VenkataRao J. (2014): Biosynthesis and wound healing activity of copper nanoparticles. IET Nanobiotechnology 8(4): 230-237.

Vu H.T. - Keough M.J. - Long S.M. - Pettigrove V.J. (2015): Effects of the boscalid fungicide Filan ${ }^{\circledR}$ on the marine amphipod Allorchestescompressa at environmentally relevant concentrations. Environmental Toxicology and Chemistry doi: 10.1002/etc.3247.

Yang L. - Watts D. J. (2005): Particle surface characteristics may play an important role in phytotoxicity of alumina nanoparticles. Toxicology Letters 158: 122-132.

Yao K. S. - Li S. J. - Tzeng K. C. - Cheng T. C. - Chang C. Y. - Chiu C.Y. - Liao C. Y. - Hsu J. J. - Lin Z. P. (2009): Fluorescence silica nanoprobe as a biomarker for rapid detection of plant pathogens. Advanced Material Research 79: 513-516.

Zong X. - Wang W. - Wei H. - Wang J. - Chen X. - Xu L. - Zhu D. - Tan Y. - Liu Q. (2014): Rapid detection of Prunus necrotic ringspot virus using magnetic nanoparticle-assisted reverse transcription loop-mediated isothermal amplification. J. Virol. Methods. 2014 Nov; 208: 85-89. doi: 10.1016/j.jviromet.2014.07.033.

Zhu H. - Han J. - Xiao J.Q. - Jin Y. (2008): Uptake translocation and accumulation of manufactured iron oxide nanoparticles by pumpkin plants. Journal of Environmental Monitoring 10: 713-717. 